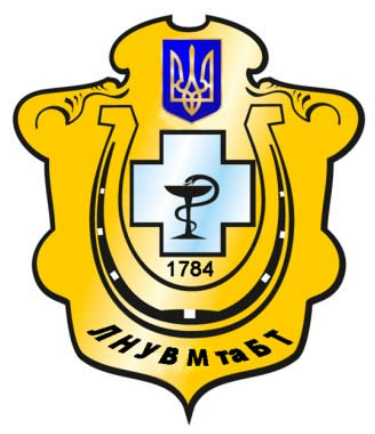

Науковий вісник Львівського національного університету ветеринарної медицини та біотехнологій імені С.3. Гжицького

Scientific Messenger of Lviv National University of Veterinary Medicine and Biotechnologies named after S.Z. Gzhytskyj

doi:10.15421/nvlvet6934

ISSN 2413-5550 print

ISSN 2518-1327 online

$\underline{\text { http://nvlvet.com.ua/ }}$

УДК 338.49 : 332.135 : [332.122 : 338.43] (477) (438)

\title{
Інфраструктурне забезпечення конвергенції економіки сільських територій в українсько-польському транскордонному регіоні
}

\author{
В.А. Чемерис ${ }^{1}$, К.К. Куцаб-Бонк ${ }^{2}$, М.М. Янків ${ }^{3}$ \\ chemerus64@gmail.com,kkucab_bak@poczta.onet.pl,mariya.yankiv@gmail.com \\ ${ }^{I}$ Львівський національний університет ветеринарної медицини та біотехнологій імені С.3. Гжицького, \\ вул. Пекарська, 50, м. Львів, 79010, Украӥна; \\ ${ }^{2}$ Вища державна техніко-економічна школа імені Броніслава Маркєвича в м. Ярославі, \\ вул. Чарнецького, 16, м. Ярослав, 37500, Польщза; \\ ${ }^{3}$ ДУ «Інститут регіональних досліджень імені М.І. Долішнього НАН Украӥни», \\ вул. Козельницька, 29, 79057, м.Львів, Украӥна
}

\begin{abstract}
Розглядаються основні проблеми економічного розвитку прикордонних сільських територій Украйни в умовах активізації транскордонного співробітнищтва з Польщею. Доводиться, щчо конвергенція економіки сільських територій в украӥнсько-польському транскордонному регіоні виступає важливим чинником поглиблення інтеграції між обома державами та індикатором успішності євроінтеграційного поступу Украӥни. Вона забезпечує інтенсифікацію руху товарів і фінансових ресурсів між сусідніми прикордонними територіями обох держав. Крім того, завдяки конвергенції відбувається зближення стандартів ведення аграрного бізнесу, щз створює сприятливі передумови для реалізації спільних транскордонних інвестиційних проектів у межах сільських територій украӥнсько-польського прикордоння.

Особливу увагу акиентовано на необхідності удосконалення інфраструктурного забезпечення сільських територій в українсько-польському транскордонному регіоні. Обгрунтовано, щзо модернізація інфраструктури чинить суттєвий позитивний вплив на ефективність використання потенщіалу сільських територій України в умовах транскордонного співробітництва із Польщею. Акцентовано увагу на актуальності інновачійного розвитку прикордонної, транспортнологістичної, інформаційної та маркетингової інфраструктури, передусім з огляду на економічні виклики, породжені сучасним етапом європейської інтеграції. Доведено, шьо особливо важливого значення з погляду поширення конвергенції в українсько-польському транскордонному регіоні сьогодні набуває розвиток інституційної інфраструктури, яка забезпечує укорінення нових форм економічної інтеграчії між суб'єктами аграрного ринку.

Запропоновано заходи, орієнтовані на першочерговий розвиток інфраструктури сільських територій в українськопольському транскордонному регіоні. Зокрема, з метою стимулювання конвергентних процесів між прикордонними сільськими територіями Украӥни та Польщі пропонується здійснити низку заходів, пов'язаних з модернізацією транспортних комунікацій, включаючи розбудову транспортно-логістичних иентрів, покращити рівень інформачійного забезпечення сільських територій у прикордонних регіонах України, передусім на основі покращення доступу до Інтернету та мобільного зв'язку, а також стимулювати прочеси сільськогосподарської коопераиії та налагодження сучасних форм транскордонних економічних взаємодій між господарюючими суб' 'ктами аграрної економіки, локалізованими по різні боки кордону.

Ключові слова: інфраструктурне забезпечення, конвергенція, економіка, сільські території, транскордонний регіон, українсько-польське прикордоння, транскордонне співробітництво.
\end{abstract}

\section{Инфраструктурное обеспечение конвергенции экономики сельских територий в украинско-польском трансграничном регионе}

\author{
В.А. Чемерис ${ }^{1}$ К.К. Куцаб-Бонк², М.М. Янкив ${ }^{3}$ \\ chemerus64@gmail.com,kkucab_bak@poczta.onet.pl, mariya.yankiv@gmail.com
}

\section{Citation:}

Chemerus, V., Kutsab-Bonk, K., Yankiv, M. (2016). Infrastructure providing of the convergence of economy of rural areas in the ukrainian-polish cross-border region. Scientific Messenger LNUVMBT named after S.Z. Gzhytskyj, 18, 2(69), 176-182. 


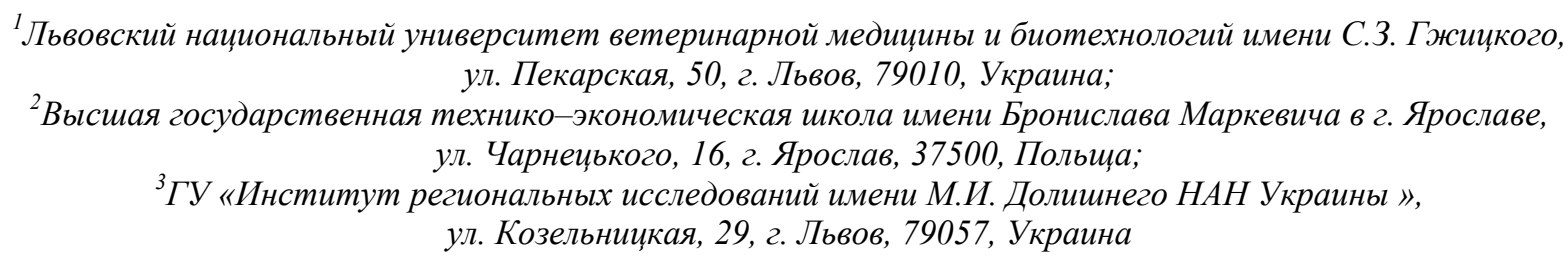

Рассматриваются основные проблемы экономического развития приграничных сельских территорий Украины в условиях активизации трансграничного сотрудничества с Польшей. Доказано, что конвергенция экономики сельских территорий в украинско-польском трансграничном регионе является важным фактором углубления интеграции между обоими государствами и индикатором успешности евро интеграционного движения Украины. Особое внимание акиентировано на необходимости совершенствования инфраструктурного обеспечения сельских территорий в украинско-польском трансграничном регионе. Обосновано, что модернизачия инфраструктуры оказывает существенное позитивное влияние на эффективность использования потенциала сельских территорий Украины в условиях трансграничного сотрудничества с Польшей. Предложены мероприятия, ориентированные на первоочередное развитие пограничной, транспортнологистической, информационно-коммуникаиионной и маркетинговой инфраструктуры сельских территорий в украинскопольском трансграничном регионе. Именно эти виды инфраструктуры выделены как основные в контексте углубления конвергентных процессов в развитии приграничных сельских территорий Украины и Польши на современном этапе европейской интеграиии.

Ключевые слова: инфраструктурное обеспечение, конвергенция, экономика, сельские территории, трансграничный регион, украинско-польское пограничье, трансграничное сотрудничество.

\title{
Infrastructure providing of the convergence of economy of rural areas in the ukrainian-polish cross-border region
}

\author{
V. Chemerus ${ }^{1}$, K. Kutsab-Bonk ${ }^{2}$, M. Yankiv ${ }^{3}$ \\ chemerus64@gmail.com,kkucab_bak@poczta.onet.pl, mariya.yankiv@gmail.com \\ ${ }^{1}$ Lviv National University of Veterinary Medicine and Biotechnologies named after S.Z. Gzhytskyi, \\ Pekarska Str., 50, Lviv, 79010, Ukraine; \\ ${ }^{2}$ The Bronislaw Markiewicz State Higher School of Technology and Economics in Yaroslaw, \\ Charnetsky Str., 16, Yaroslav, 37-500, Poland; \\ ${ }^{3} S U$ «Institute of Regional Studies named after M.I. Dolishniy NAS of Ukraine» \\ Kozelnicka Str., 29, Lviv, 79057, Ukraine
}

\begin{abstract}
Article considers the main problem of economic development of rural areas bordering Ukraine in conditions of intensification cross-border cooperation with Poland. We proved that the convergence of the economy of rural areas in the Ukrainian-Polish cross-border region is an important factor in deepening integration between the two countries and an indicator of the success of European integration of Ukraine. It provides an intensification of the movement of goods and financial resources between neighboring border areas of both countries. In addition, due to convergence there is rapprochement of standards of conduct of agrarian business that creates favorable conditions for implementation of joint cross-border investment projects within the rural UkrainianPolish border territories.

The special attention is accented on the necessity of improvement of the infrastructural providing of rural Ukrainian-Polish cross-border region. We substantiated that modernization of infrastructure has a significant positive impact on the effectiveness of the use of potential of rural territories of Ukraine in conditions of cross-border cooperation with Poland. The attention is focused on the relevance of the innovation development of border, transport and logistics, information and marketing infrastructure, especially due to the economic challenges generated by the current stage of European integration. We have proved that especially great importance in terms of spread convergence in Ukrainian-Polish cross-border region today acquires the development of institutional infrastructure that provides rooting of new forms of economic integration between the subjects of the agrarian market.

We have proposed measures focused on the priority infrastructure development in rural areas in the Ukrainian-Polish crossborder region. In particular, in order to stimulate convergence processes between rural areas bordering Ukraine and Poland it is suggested to implement a number of measures related to modernization of transport communications, including the development of transport and logistics centers, improve the level of information support in rural areas in the border regions of Ukraine, especially on the basis of improving access to the Internet and mobile communications, and stimulate processes of agricultural cooperation and adjustment modern forms of cross-border economic interactions between economic entities of agrarian economics, localized on both sides of the border.
\end{abstract}

Key words: infrastructural provision, convergence, economics, rural areas, cross-border region, the Ukrainian-Polish borderland, cross-border cooperation.

\section{Вступ}

Активізація євроінтеграційних процесів, яка супроводжується адаптацією в Україні цілої низки інституційних стандартів ЄС у зв'язку $з$ підписанням
Угоди про асоціацію, чинить значний вплив на основні сектори вітчизняної економіки, включаючи сільське господарство. Водночас, трансформація аграрного сектору нашої держави під впливом вказаних інституційних змін, тягне за собою постання нових 
викликів для економіки сільських територій, основу виробничого потенціалу яких формує сільське господарство. Передусім, це стосується прикордонних регіонів Західної України, де переважають особисті господарства населення.

У зв'язку із цим актуалізується необхідність дослідження перспективних напрямів підвищення ефективності функціонування економіки прикордонних сільських територій України в сучасних умовах європейської інтеграції. Особливо це стосується пріоритетів модернізації сільської економіки на основі використання потенціалу транскордонного співробітництва та реалізації інфраструктурних проектів, спрямованих на конвергенцію економік суміжних прикордонних регіонів України та сусідніх із країн-членів EC.

При цьому, враховуючи якість та динаміку транскордонної співпраці, а також спеціалізацію в міжнародному поділі праці, для прикордонних територій нашої держави особливої вагомості набуває співпраця, орієнтована на розвиток сільської економіки, в межах українсько-польського транскордонного регіону.

Враховуючи це, метою статті є виявлення резервів нарощування економічного потенціалу сільських територій українсько-польського транскордонного регіону на основі удосконалення інфраструктури та поширення конвергентних процесів.

\section{Матеріал і методи досліджень}

Методологічну основу наукового дослідження, виконаного у процесі написання статті, складають теоретичні положення інституціоналізму, неокласичної наукової школи, а також теорії регіональної економіки і транскордонного співробітництва.

Для розв'язання окремих наукових проблем, висвітлених у цій публікації, застосовувалися методи аналізу та синтезу, монографічний, наукових порівнянь і соціологічного дослідження.

\section{Результати та їх обговорення}

Розвиток прикордонних сільських територій України в умовах активізації євроінтеграційних процесів значною мірою залежить від характеру транскордонного співробітництва із сусідніми країнами-членами ЄC. Найбільш повно весь спектр проблем такого співробітництва виявляється у контексті дослідження економіки транскордонних регіонів.

У вітчизняній науковій літературі під транскордонним регіоном часто розуміється територія сусідніх адміністративно-територіальних одиниць різних країн, які мають прикордонне розташування. При цьому наголошується, що ознака регіональної делімітації території має транскордонний характер. Основними критеріями ідентифікації такого регіону вважаються:

- рівень однорідності (географічної, економічної, культурної спільності, розвиток регіональної ідентичності тощо);
- відсутність або низька формалізація державного кордону;

- високий рівень розвитку і вагомий статус;

- розміщення щодо кордонів $\mathrm{CC}$;

- існування співпраці понад кордонами та інституціоналізація структур такої співпраці (Antoniuk, 2005).

У цьому контексті кожен транскордонний регіон володіє низкою характерних ознак, дослідження яких у сучасних умовах європейської інтеграції, дає можливість виявити ключові бар'єри розвитку конвергентних процесів у його межах та окреслити перспективні напрями функціонування різних структуроутворюючих ланок цього регіону в найближчій і довгостроковій перспективі.

По-перше, конвергенція у транскордонному регіоні має задовольняти вимозі його просторової компактності (неперервності транскордонного простору). Це означає, що рух товарів, матеріально-технічних ресурсів і людей у межах транскордонного регіону повинен бути максимально спрощеним, а також фактично не обмежуватись кордонами, візовими процедурами та митними режимами.

По-друге, для довготривалої активізації економічного співробітництва на основі вирівнювання економічних пропорцій у межах транскордонного регіону, необхідна наявність спільних, інтегрованих виробництв, які функціонують на засадах ринкової кооперації, спираючись на переваги міжнародного поділу праці. Передусім це стосується транскордонних кластерів та наукових парків, орієнтованих на реалізацію інвестиційних проектів за участю господарюючих суб'єктів прикордонних територій обох держав, зокрема в туристично-рекреаційній, інноваційнотехнологічній, транспортно-логістичній і торговельно-збутовій сферах.

По-третє, економіка транскордонного регіону може набути ознак стабільної (еволюційної) конвергенції лише за умови існування єдиного інституційного поля, яке формується за допомогою регуляторних актів міждержавного, національного та місцевого рівня, охоплюючи при цьому, крім формальних, також і неформальні інститути, що набули поширення у транскордонному просторі. В цьому сенсі ключового значення для розвитку конвергенції у транскордонному регіоні в сучасних умовах європейської інтеграції набуває узгодження між собою стратегій розвитку кожного з прикордонних регіонів - учасників транскордонного співробітництва, а також формування на цій основі спільних стратегій розвитку для всього транскордонного регіону.

Водночас, ключовою ланкою, яка визначає рівень однорідності економіки по різні боки кордону, перетворюючи транскордонний регіон в єдиний економічний простір, є інфраструктура. Стан іiі основних ланок, а саме транскордонної інформаційнокомунікаційної мережі, транспортного господарства, включаючи якість доріг і роботу логістичних центрів, наявність достатньої кількості прикордонних переходів тощо, відображає спроможність господарюючих 
суб'єктів по різні боки кордону досягати приблизно однакового рівня свого розвитку.

Найбільш виразно якість інфраструктурного забезпечення впливає на конвергенцію економіки сільських територій. Адже, будучи за своє природою менш інвестиційно-привабливими ніж міські агломерації, сільські території потребують додаткових важелів впливу на потенційних інвесторів, серед яких розвиток та модернізація інфраструктури виходить на одне із перших місць. Прикладом може слугувати ситуація в українсько-польському транскордонному регіоні. Так, прикордонні області Західної України та сусідні із ними воєводства Східної Польщі, володіючи приблизно однаковим агровиробничим потенціалом, кардинально відрізняються між собою рівнем розвитку інфраструктури аграрного ринку. Якщо польські села пов'язані між собою та з іншими регіонами держави сучасною мережею автомобільних доріг і залізничних колій, не маючи при цьому суттевих проблем із доступом до інформаційних ресурсів, то їх українські відповідники користуються дорогами здебільшого незадовільної якості, а їх доступ до Інтернету, мобільного зв'язку чи інформаційних сервісів перебуває на вкрай низькому рівні.

Акцентуючи увагу на бар'єрах економічної конвергенції сільських територій в українсько-польському транскордонному регіоні, не можна оминути увагою таку надзвичайно вадливу проблему, як обмеження інтенсивності руху між прикордонними територіями обох країн, зумовлену недостатнім розвитком прикордонної інфраструктури. Адже тривалий час простою на кордоні та наявність складних, а часто і відверто корупційних схем його перетину, подекуди виявляються просто неприйнятними для тих агровиробників, які експортують сільськогосподарські товари, особливо якщо мова йде про товари, які швидко псуються.

Таким чином, однією із основних передумов конвергенції економіки сільських територій в українсько-польському транскордонному регіоні $є$ радикальне збільшення проникності кордону для сільгоспвиробників. Збільшення проникності повинно полягати не тільки у формально-правових аспектах, але і в модернізації всієї прикордонної інфраструктури. Так, польські дослідники Й. Шляхта, Й. Залевскі та В. Дзємяновіч відзначають, що в регіональному масштабі найважливішими $є$ технологічні та інфраструктурні зміни, пов'язані зі збільшенням кількості пунктів перетину кордону і покращенням дорожньої мережі, яка обслуговує ці пункти (Shliakhta, 2000).

Слід наголосити на тому, що збільшення проникності кордону - це тільки початок, первинний імпульс для започаткування процесу конвергенції економіки сільських територій по обидва боки кордону. Воно дає змогу самостійно встановити (або часом відновити) двосторонні, зокрема економічні зв'язки між агровиробниками, розташованими по різні боки кордону. Водночас, без прийняття інших інфраструктурних рішень воно може також привести до нерівномірного розподілу економічної користі між двома сторонами прикордоння. Аби запобігти можливим негативним явищам у цьому контексті, необхідне постійне збіль- шення привабливості прикордонних сільських територій та їх конкурентоспроможності в межах усього українсько-польського транскордонного регіону.

На жаль, сучасний стан співробітництва між сільськими територіями в українсько-польському транскордонному регіоні обумовлений низкою об'єктивних чинників та перешкод, які негативно впливають на інституційну інфраструктуру, ускладнюючи тим самим використання кордону як стимулюючого, а не гальмуючого чинника транскордонної конвергенції.

Так, сьогодні в українсько-польському транскордонному регіоні заблокованою виявляється ціла низка ринкових інститутів, пов'язаних з інтенсифікацією обміну інформацією та інноваційним розвитком в системі комунікацій між виробниками, посередниками, споживачами та іншими суб'єктами аграрного ринку. На відміну від Польщі, у прикордонних сільських територіях України не набули достатнього поширення такі суб'єкти інформаційно-комунікаційної інфраструктури, як агроконсалтингові фірми, центри ринкової інформації, інформаційно-дорадчі служби тощо. I хоча на тлі інших регіонів нашої держави у прикордонних областях Західної України ситуація виглядає відносно кращою, діяльність більшості складових інформаційно-комунікаційної інфраструктури аграрного ринку тут не відзначаються достатньою активністю, а сфера компетенції переважної їх частини, не відповідає тим стандартам, якими керуються аналогічні інституції в У Польщі та інших краінах-членах ЄC.

Водночас, конвергенція економіки сільських територій у транскордонному регіоні неможлива в умовах інформаційних асиметрій, зумовлених недостатнім розвитком інформаційно-комунікаційної мережі по український бік кордону. Адже насичення транскордонного простору якісною та актуальною інформаці$\epsilon ю$ є важливим засобом ефективного усунення тих ключових бар'єрів, які обмежують конкурентоспроможність сільських територій через блокування сучасних форм їх транскордонної співпраці.

В сучасних умовах, з огляду на те що світ переходить в добу інформаційної цивілізації, функціонування об'єктів інформаційно-комунікаційної інфраструктури набуває деталі вагомішого значення. Саме завдяки їм агровиробники отримують змогу своєчасно і в повному обсязі передавати необхідну інформацію до споживачів продовольчих товарів, а останні, у свою чергу, долати інформаційні асиметрії, пов'язані 3 функціонуванням аграрного ринку в межах усього транскордонного регіону. Таким чином, розвиток інформаційно-комунікаційної інфраструктури набуває дальшої більшої вагомості та значимості.

У цьому контексті вітчизняні дослідники відзначають необхідність адаптації інформаційної інфраструктури сільських територій до зростаючих вимог сучасної «е-економіки» (електронної економіки). Передусім це стосується розвитку систем обробки інформації та підготовки кваліфікованих кадрів для органів місцевого самоврядування сільських територіальних громад, спроможних ефективно виконувати свої функції в умовах наростання потужності та інтенсивності транскордонних інформаційних потоків. 
При цьому кожна сільська територія повинна бути представленою у «всесвітній павутині», а інформація про іiі інвестиційні перспективи та потенціал реалізації транскордонних проектів має широко популяризуватися у середовищі внутрішніх і зовнішніх інвесторів (Borshchevsky, 2003).

Прогалини в розвитку інформаційнокомунікаційної інфраструктури сільських територій українсько-польського транскордонного регіону, викликані браком інновацій як організаційноуправлінського, так і техніко-технологічного характеру, призводять до укорінення та самовідтворення цілої низки негативних тенденцій, пов'язаних 3 неефективною структурою виробництва та розподілу сільськогосподарської продукції, нераціональним розміщенням трудових і матеріальних ресурсів села, вичерпуванням соціально-економічного потенціалу сільських територій.

Так, одна $з$ основних проблем у розвитку інформаційно-комунікаційної інфраструктури сільських територій досліджуваного транскордонного регіону, особливо з погляду перспектив європейської інтеграції України після підписання Угоди про асоціацію 3 $\mathrm{\epsilon C}$, полягає у недостатній включеності у цей процес вищих навчальних закладів та наукових установ аграрного профілю. Це суттєво знижує потенціал економічної конвергенції між прикордонними сільськими територіями України та Польщі. Насамперед, це пов'язано 3 діючою системою планування науководослідної та навчальної діяльності вказаних інституцій. Адже академічна наука орієнтується або на фундаментальні дослідження, або на прикладні теми, в яких основний акцент робиться на організаційноуправлінську компоненту з виходом на рекомендації для органів державної влади. Це обмежує можливості інформаційно-комунікаційного супроводу учасників аграрного ринку.

Те ж саме стосується і пріоритетів діяльності ВНЗ аграрного профілю, навчальні плани яких формуються, виходячи не стільки з потреб аграрного бізнесу, скільки за колишніми лекалами, орієнтованими на обслуговування великих сільськогосподарських підприємств, які, у більшості своїй не націлені на функціонування в умовах ринкової конкуренції. Як наслідок, переважна частина професорсько-викладацького складу, не тільки невмотивована, але і просто не готова працювати в режимі дорадників або консультантів 3 фермерськими чи особистими господарствами населення.

3 цього приводу президент Національної асоціації сільськогосподарських дорадчих служб України Р. Корінець відмічає: «Американська модель - це дорадництво, побудоване на базі університетів. На жаль, в Україні університети за своїми підходами та методами роботи дуже відрізняються від американських. Український університет - це, в першу чергу, навчальний центр, а американський - дослідницький центр. Американський науковець більше зорієнтований на результат дослідницької роботи, а український - на класичні дослідження або на навчання. Німецька модель зорієнтована переважно або на аграрні палати, або на приватний бізнес. Якщо говорити про данську модель дорадчої служби, то вона працює через об'єднання фермерів. Це практично організація, підконтрольна фермерам. На жаль, в Україні фермери ще не проявляють такої активності щодо створення власної системи консультування. Польська та французька моделі побудовані на державному дорадництві. Якщо для французів це традиційна система, яка реалізується через аграрні палати, то в Польщі це виключно державні структури. I, як показує практика, для країн 3 перехідною економікою найприйнятнішою $\epsilon$ модель, коли є державний осередок і він фінансується ритмічно. А потім уже можна перейти і до приватизації цих дорадчих служб, як це сталося в Британії. Там щойно уряд побачив, що фермер може платити за дорадчі послуги, то розпочався процес приватизації дорадчих служб. Значним джерелом для оплати сільськогосподарських дорадчих послуг залишаються проекти міжнародної технічної допомоги. Зокрема, на їхніх коштах практично повністю побудовано діяльність Львівської аграрної дорадчої служби. Та я не вважаю такий підхід перспективним. Річ у тому, що технічні проекти працюють недовго. Вони закриваються по тому, як тільки виконають поставлені перед ними завдання».

Слід також підкреслити відсутність дієвої державної системи поширення науково-технічної та ринкової інформації в межах українсько-польського транскордонного регіону загалом, так на його сільських територіях, зокрема. Відповідні приватні ресурси 3 обмеженим доступом вимагають адекватної оплати послуг, що за умови реальних проблем бюджетного фінансування здійснюються фактично за залишковим принципом, як правило наприкінці бюджетного року. Такий підхід суттєво ускладнює розвиток сільського господарства, яке виступає основою економічного потенціалу сільських територій українськопольського транскордонного регіону, а також унеможливлює диверсифікацію сільської економіки.

Таким чином, слід відмітити, що значна частина складових інформаційно-комунікаційної інфраструктури сільських територій українсько-польського транскордонного регіону, в силу різних причин, виявляються неспроможними виконувати покладених на них функцій.

На думку польських дослідників, вирішенню цієї проблеми може посприяти запровадження стратегічного планування розвитку транскордонної конвергенції сільських територій, яка повинна враховувати інтереси як українських так і польських учасників транскордонного співробітництва, одночасно опираючись на підтримку ЄС. Така стратегія має передбачати:

- $\quad$ зближення структури економік сільських територій прикордонних регіонів України та Польщі, у якій, крім аграрного сектору, доцільно розвивати диверсифікацію виробництва і послугову діяльність;

- поглиблення транскордонної співпраці між чисельними, часом досить міцними академічними та науковими осередками з обох боків кордону;

- у узгодження та проведення спільних безпекових і природно-захисних дій, які одночасно дають 
можливість підвищити ефективність використання фізично-географічних ресурсів прикордонних сільських територій, розташованих по обидва боки кордону, 3 метою розвитку туристично-рекреаційної сфери;

- $\quad$ формування спільної транспортно-логістичної інфраструктури в межах усього транскордонного простору між Україною та Польщею, орієнтованої на обслуговування не лише спільних інвестиційних проектів, але і на виконання загальноєвропейських трансконтинентальних завдань;

- розвиток мережі залізничного сполучення, яка з'єднує метрополійні центри прикордонних регіонів країн-членів СС і прикордонних територій Польщі та України;

- $\quad$ активізація участі інвесторів з СС у реалізації інноваційних проектів у межах сільських територій українсько-польського транскордонного регіону, насамперед у високотехнологічних секторах економіки: IT-індустрія, сучасне приладобудування, альтернативна енергетика, фармацевтична промисловість тощо.

Важливого значення для підвищення якості інфраструктурного забезпечення конвергенції економіки сільських територій в українсько-польському транскордонному регіоні має розбудова інформаційнокомунікаційної та інституційної інфраструктури. Передусім це стосується реалізації спільних проектів, орієнтованих на популяризацію економічного потенціалу цих територій у середовищі майбутніх інвестоpiв.

Наприклад, одним із прикладів успішного вирішення цього завдання $\epsilon$ реалізація проекту польськоукраїнської транскордонної співпраці зі створення "Центру Польсько-Української Співпраці", який діяв із лютого 2009 р. до січня 2011 р., охоплюючи прикордонні регіони обох держав. Головним осередком реалізації проекту було містечко Краснік, що знаходиться на території Люблінського воєводства. Місто $є$ прикладом зразкових рішень у галузі самоврядного життя в широкому розумінні, організації і активності місцевої громади, створення локальних та міжнародних партнерств. Загальна мета проекту - це зростання трансферу знань та добрих практик з краще розвинених регіонів (Польща) до менш розвинених (Україна). Пряма мета - це створення польсько-української системи обміну знань і досвіду для публічної адміністрації, громадських організацій та господарських суб'єктів, а також популяризація транскордонної співпраці у галузі екологічного туризму. Частина заходів, запланованих у проекті, - навчальні візити, економічні семінари, конференції відбулися в Красніку і в Любліні.

До інших пріоритетних завдань, спрямованих на розвиток інфраструктурного забезпечення конвергенції економіки сільських територій в українськопольському транскордонному регіоні можна віднести: залучення коштів іноземних інвесторів і міжнародних донорських організацій на розбудову мережі транскордонних автомобільних доріг і залізничних колій, а також формування в межах сільських територій українсько-польського прикордоння низки сучасних тра- нскордонних транспортно-логістичних центрів. Крім того, в сучасних умовах дедалі більше актуалізується проблема розбудови маркетингової та інституційної інфраструктури українсько-польського транскордонного аграрного ринку, пов'язана зі створенням транскордонних аграрних кластерів та агро-індустріальних парків, започаткування діяльності транскордонних ярмарків сільськогосподарської продукції та гуртових ринків.

\section{Висновки}

Конвергенція економіки сільських територій українсько-польського транскордонного регіону в сучасних умовах одночасно виступає, як каталізатором, так і індикатором успішного розвитку європейської інтеграції України. У першому разі, вона стимулює транскордонну співпрацю шляхом активізації транскордонного товарообміну сільськогосподарськими товарами на основі вирівнювання якості життя та стандартів ведення бізнесу по обидва боки кордону. У другому випадку конвергенція відображає зближення прикордонних сільських територій України та Польщі за низкою важливих параметрів, які виявляються у зростанні доходу на душу населення, прибутковості сільського господарства та якості людського капіталу прикордонних сільських територій.

Одним із пріоритетних напрямів посилення конвергенції в розвитку економіки сільських територій українсько-польського транскордонного регіону $\epsilon$ удосконалення їх інфраструктурного забезпечення. Ключовими завданнями у цьому контексті є: модернізація прикордонної інфраструктури та збільшення кількості сучасних прикордонних переходів між Україною та Польщею, розбудова мережі автомобільних доріг та здійснення інвестицій в об'єкти транспортно-логістичної інфраструктури в межах сільських територій у прикордонних областях Західної України, а також інтенсифікація обміну інформацією та модернізація інформаційно-комунікаційної інфраструктури сільських територій українсько-польського транскордонного регіону.

Перспективи подальших досліджень. Перспектива подальших досліджень у руслі окресленої проблематики пов'язана із виявленням резервів державноприватного партнерства як чинника залучення додаткових фінансових ресурсів у розбудову інфраструктури сільських територій українсько-польського транскордонного регіону. Одним із конкретних аспектів щодо вирішення цього завдання може стати розробка пропозицій, спрямованих на розвиток інфраструктури прикордонних сільських територій України у контексті їх економічної конвергенції з сусідніми прикордонними сільськими територіями Польщі на основі проведення децентралізації влади та здійснення адміністративно-територіальної реформи.

\section{Бібліографічні посилання}

Borshchevskyi, V. (2003) Inozemni investytsii yak chynnyk rehionalnoho rozvytku [Foreign investment 
as a factor of regional development]. Finance of Ukraine. 10, 108-117 (In Ukrainian).

Ekspertyzy, yaki vykonuvalysia na zamovlennia Ministerstva rehionalnoho rozvytku na potreby opratsiuvannia Stratehii suspilno-ekonomichnoho rozvytku skhidnoi Polshchi do 2020 roku. [Examination that were executed by order of the Ministry of regional development on the need to develop a strategy of socialeconomic development of Eastern Poland until 2020]. Vol. II; Warsaw, 2007 (in Ukrainian).

Antoniuk, N. (2005) Ievropeiskyi Soiuz: polityka, ekonomika, pravo [The European Union: Politics, Economics, Law]. Lviv, Lviv national University named after Ivan Franko (in Ukrainian).
Silskohospodarske doradnytstvo prokladaie Ukraini shliakh do Yevropy [Agricultural consulting paves Ukraine's way to Europe]. Retrieved from: http://ar25.org/article/silskogospodarskedoradnyctvo-prokladaye-ukrayini-shlyah-doyevropy.html (in Ukrainian).

Shliakhta, I. (2000) Stratehiia suspilno-ekonomichnoho rozvytku skhidnoi Polshchi do 2020 roku (proekt do konsultatsii) [Strategy of the socio-economic development of Eastern Poland until 2020 (the project to consultation)]. Warsaw, The Ministry of regional development (in Ukrainian).

Стаття надійшла до редакиії 16.09.2016 